This article is available in PDF-format, in colour, at:

http://www.wydawnictwa.ipo.waw.pl/materialy-wysokoenergetyczne/materialy-wysokoenergetyczne12_1/HEM_0111_E.pdf

Materialy Wysokoenergetyczne / High Energy Materials, 2020, 12 (1), 184 - 191; DOI 10.22211/matwys/0111E ISSN 2083-0165

Copyright (C) 2020 Łukasiewicz Research Network - Institute of Industrial Organic Chemistry, Poland

(C) $(9)$ Article is available under the Creative Commons Attribution-Noncommercial-NoDerivs 3.0 license CC BY-NC-ND 3.0.

Research paper / Praca doświadczalna

First published in Polish in 2015.

\title{
Application of explosive metal cladding in the manufacture of new, advanced layered materials exemplified by titanium Ti6Al4V - aluminium AA2519 bonding \\ Zastosowanie technologii wybuchowego platerowania metali do wytwarzania nowych zaawansowanych materiałów warstwowych na przykładzie połączenia tytan Ti6Al4 - aluminium AA2519
}

\author{
Aleksander Gałka \\ Zakład Technologii Wysokoenergetycznych „Explomet” Gałka, Szulc Sp. J., 100H Oświęcimska Street, \\ 45-641 Opole, Poland \\ E-mail: agalka@op.onet.pl
}

\begin{abstract}
Explosive metal cladding technology has been extensively developed since the mid-20th century. It is an area with the largest use of explosives for civil purposes, apart from mining. The global production of these materials runs at tens of thousands of square metres annually. Explosive bonding enables the production of a wide range of intermetallic compositions where, in many cases, no alternative methods are available. As an example, layered products include clad plates made of light metals, e.g. titanium, aluminium, magnesium showing different melting points, densities and hardness. Each new material combination requires an adaptation of the technology used by selecting suitable bonding parameters and new modified explosives.

Several variants of Ti6Al4V/AA2519 explosive alloy bonding technology were created. The clad plates were tested using destructive and non-destructive techniques to determine bond strength and integrity. The study aimed to create new materials with improved ballistic resistance for structures used in the aviation and space industry.

Streszczenie: Technologia wybuchowego platerowania metali rozwija się intensywnie od połowy minionego wieku. Jest to dziedzina produkcji, w której cywilne zużycie materiatów wybuchowych $(M W)$, poza górnictwem, jest największe. Światowa produkcja platerów wytwarzanych ta metoda wynosi dziesiątki tysięcy metrów kwadratowych $w$ skali roku. Eaczenie wybuchowe pozwala na wytwarzanie najszerszej gamy międzymetalicznych kompozycji i w wielu przypadkach nie ma dla siebie alternatywy. Przykładem takich materiatów warstwowych sa platery z udziałem metali lekkich jak tytan, aluminium, magnez, różniących się znacznie temperaturami topnienia, gęstościa, twardościa. Każda nowa kombinacja materiałowa wymaga odpowiedniej adaptacji technologii poprzez dobór właściwych parametrów spajania i często odpowiednio zmodyfikowanych nowych $M W$.

Opracowano technologię wybuchowego taczenia stopów Ti6Al4V i AA2519 w różnych wariantach konstrukcyjnych. Platery przebadano przeprowadzając testynieniszczące i niszczace, oceniając spójność
\end{abstract}


oraz wytrzymałość mechaniczna uzyskanego połaczenia. Celem prowadzonych prac było wytworzenie nowych materiałów o podwyższonej odporności balistycznej na konstrukcje lotnicze i kosmiczne.

Keywords: explosive cladding, detonation velocity, Ti6Al4V/AA2519 clad plate

Stowa kluczowe: platerowanie wybuchowe, prędkość detonacji, plater Ti6Al4V-AA2519

\section{Foreword}

The technology of explosive metal cladding is a universal method of producing different intermetallic bonds, allows material combinations to be formed for which no alternative methods are available. Its extensive development has been continuing since the mid-20th century. The scale of production has adapted to global trends in economic development dynamics and generally shows an upward trend. Bimetals and multi-layered compositions are widely used in many industries, in particular chemical apparatus, processing and shipbuilding. The universal nature of the method lies in its ability to combine two metals with significantly different properties, including melting point, density, chemical activity where, in many cases, no alternative method is available. An example of such combinations include bimetallic materials containing titanium and aluminium alloys [1-3]. The alloys are excellent structural materials on their own due to high strength and low density, however, a permanent metallurgical bonding can produce composites with unique and interesting properties.

As part of the research project co-financed by the National Centre for Research and Development (NCBiR) with the working title: Nowe zaawansowane materiały warstwowe Al-Ti o podwyższonej odporności balistycznej na konstrukcje lotnicze i kosmiczne (New advanced layered Al-Ti materials with improved ballistic resistance for structures used in aviation and space industry) a new Ti6Al4V/AA 2519 aluminium alloy bimetal was manufactured by explosive cladding and comprehensively tested. The studies have been carried out from 2014 to 2016 as part of the scientific-industrial consortium, including:

a) Military University of Technology in Warsaw,

b) Institute of Non-Ferrous Metals in Gliwice,

c) Space Research Centre of Polish Academy of Sciences in Warsaw,

d) Warsaw University of Technology,

e) University of Technology and Life Sciences in Bydgoszcz,

f) High-Energy Technology Laboratory Explomet in Opole.

At the time of writing, the Explomet work schedule has reached its halfway point. The manufactured material underwent microstructural, non-destructive and mechanical tests and selected ballistic resistance tests. The test results included in this study are part of the research carried out by ZTW Explomet.

\section{Materials and methods}

The implementation of a successful new material production system usually requires adaptation of available technologies, including the determination of explosive cladding parameters, depending on the type and quantity of explosive material used, and the design considerations of the cladding system. A series of tests of different compositions was carried out before bonding attempts were made to select a suitable composition in view of its explosive parameters. Materials based on ammonium nitrate( $(\mathrm{V})$ and hydrocarbon propellant with inert additives (sodium chloride or silicon dioxide) were tested. The compositions include explosives commonly used in explosive metal cladding technology. As a precautionary measure, the sensitivity of the selected compositions to mechanical stimuli was assessed and the detonation wave parameters were determined using an electromagnetic method [4-6]. The research focused on detonating the designed explosives under firing range conditions and determining the detonation velocity for different charge layer thicknesses. The performance, including the detonation velocity depends on the chemical composition, physical form of the components, e.g. particle size, extended porous surface in the crystalline structure of ammonium nitrate $(\mathrm{V})$ and uniformity. Table 1 shows the chemical composition of the tested charges. 
Table 1. Chemical composition of tested explosive compositions

\begin{tabular}{|c|c|c|c|c|c|}
\hline \multirow[b]{2}{*}{$\begin{array}{c}\text { ANFO } \\
\text { designation }\end{array}$} & \multicolumn{5}{|c|}{ Chemical composition [wt.\%] } \\
\hline & $\begin{array}{c}\text { Ground ammonium } \\
\text { nitrate(V) }\end{array}$ & $\begin{array}{c}\text { Granulated/ground ammonium } \\
\text { nitrate(V) 1:1 }\end{array}$ & $\begin{array}{c}\text { Hydrocarbon } \\
\text { propellant }\end{array}$ & $\mathrm{NaCl}$ & $\mathrm{SiO}_{2}$ \\
\hline S1 & - & 95.0 & 5.0 & - & - \\
\hline S2 & - & 76.0 & 4.0 & 20 & - \\
\hline S3 & - & 76.0 & 4.0 & - & 20 \\
\hline S4 & - & 78.4 & 1.6 & 20 & - \\
\hline S5 & - & 79.2 & 0.8 & 20 & - \\
\hline S6 & - & 79.2 & 0.8 & - & 20 \\
\hline S7 & 76.0 & - & 4.0 & 20 & - \\
\hline S8 & 76.0 & - & 4.0 & - & 20 \\
\hline S9 & 79.2 & - & 0.8 & 20 & - \\
\hline S10 & 79.2 & - & 0.8 & - & 20 \\
\hline S11 & 69.3 & - & 0.7 & - & 30 \\
\hline
\end{tabular}

The test programme involved explosive bonding of bimetallic plates including two-layer Ti6A14V/ AA2519 systems:

- $3 \mathrm{~mm}+3 \mathrm{~mm}$ (series ' 3 '),

- $5 \mathrm{~mm}+5 \mathrm{~mm}$ (series ' 5 '),

- $10 \mathrm{~mm}+10 \mathrm{~mm}$ (series ' 10 '), and

- multi-layered systems (series ' $3 \mathrm{M}$ ').

The bonding attempts were made using a parallel cladding system (Fig. 1) and the following bonding variants:

a) direct Ti6A14V/AA2519 bonding,

b) Ti6Al4V/AA2519 bonding with a $1 \mathrm{~mm} 1050$ aluminium interlayer,

c) Ti6Al4V/AA2519 bonding with a $0.8 \mathrm{~mm}$ Gr 2 titanium interlayer,

d) Ti6A14V/AA2519 bonding using 2519 alloy with metallurgically rolled A11050 layer. 
a)

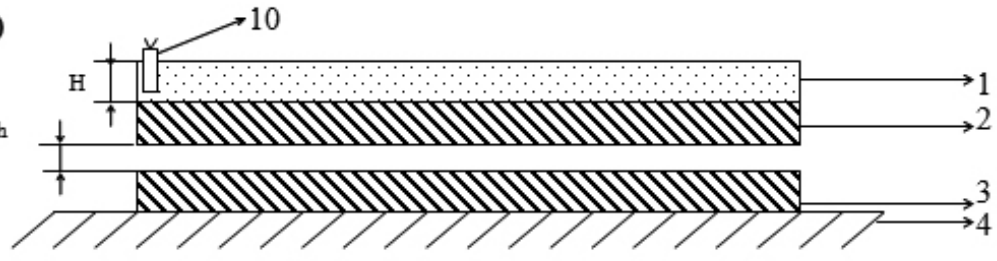

b)

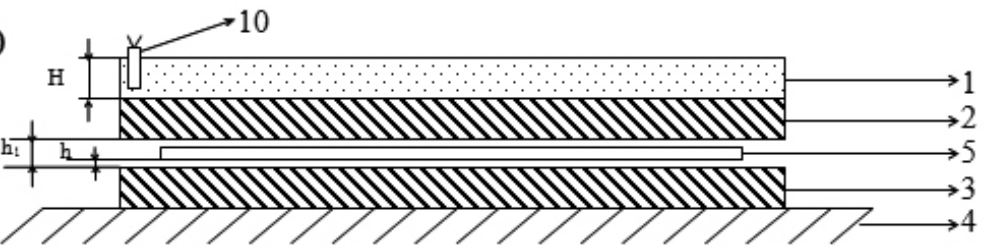

c)

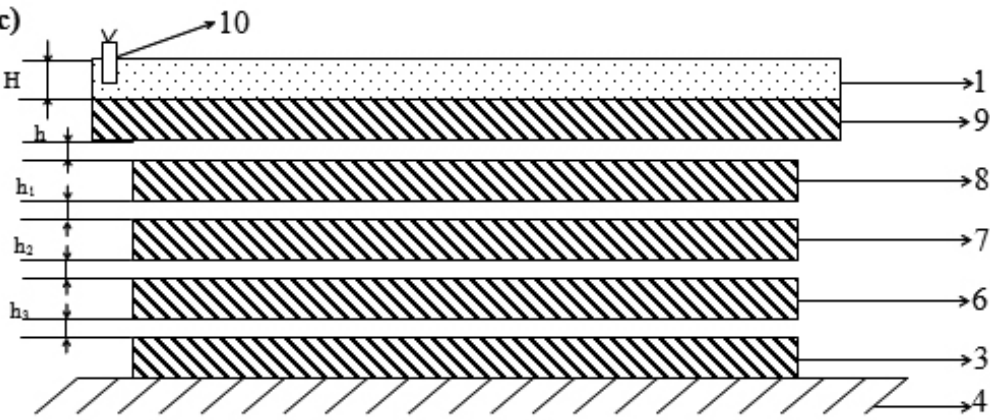

Figure 1. Explosive plate cladding configuration: a) direct bonding, b) bonding with an interlayer, c) multi-layer bonding: $H$ - explosive layer height, $h, h_{1}, h_{2}, h_{3}$ - cladder path, 1 - explosives, 2 - cladder, 3 - backer, 4 - base/anvil, 5 - interlayer, 6, 7, 8 - subsequent cladders, 9 - cladder, 10 - electric igniter

\section{Experimental section}

As expected, the tests of sensitivity of the proposed compositions to mechanical stimuli, validated the ability to safely prepare and use them in the explosive cladding process. The sensitivity to impact was min. $10 \mathrm{~J}$, whereas at $360 \mathrm{~N}$, the material did not show sensitivity to friction.

Detonation wave parameter measurements, using the electromagnetic method, was aimed at determining the effect of varying the explosive composition on the dynamics of transition in the detonation wave zone. The tests showed that using this method, the ammonium nitrate(V)-based explosive material were characterized by low detonation velocity, oxygen inbalance and an increased inert component content, yielding result which are difficult to interpret and which show a high margin of error. The mass velocity curves differ significantly from those of stronger composite materials. The dynamics of the pressure progression at the shock wave front in the charge is extended in time, and many variations in the recorded impulse are observed due to the complexity of chemical reactions in the detonation wave zone of multi-component compositions including non-explosive substances, and extended reaction time. The comparative analysis verified that for oxygen balanced explosives, increasing the inert component decreases the detonation pressure and increases the chemical peak width. Additional increases in propellant content in the composition further reduce the expenditure of energy, i.e. decreases the detonation pressure and the reaction time in the detonation wave zone. The type of inert 
substance and its conversion mode in the detonation wave zone affects the shape of the chemical peak detected. Due to its low melting point, the presence of sodium chloride in the explosive means that the chemical peak of the detonation wave is slightly higher compared to a silicon dioxide content. The observed differences should affect the explosive cladding process and may aid in interpreting the results. Often, measurements of explosive detonation velocity of different chemical compositions yield similar results, and in the explosive cladding process different results can be observed in the morphology of the bond, which most probably results from the variable duration of the effect of increased thermodynamic parameters of the detonation products.

To measure the detonation velocity of the proposed explosives, a multi-channel Explomet Fo Multimode optical meter with five independent timers was used. Figure 2 shows the measurement schematic.

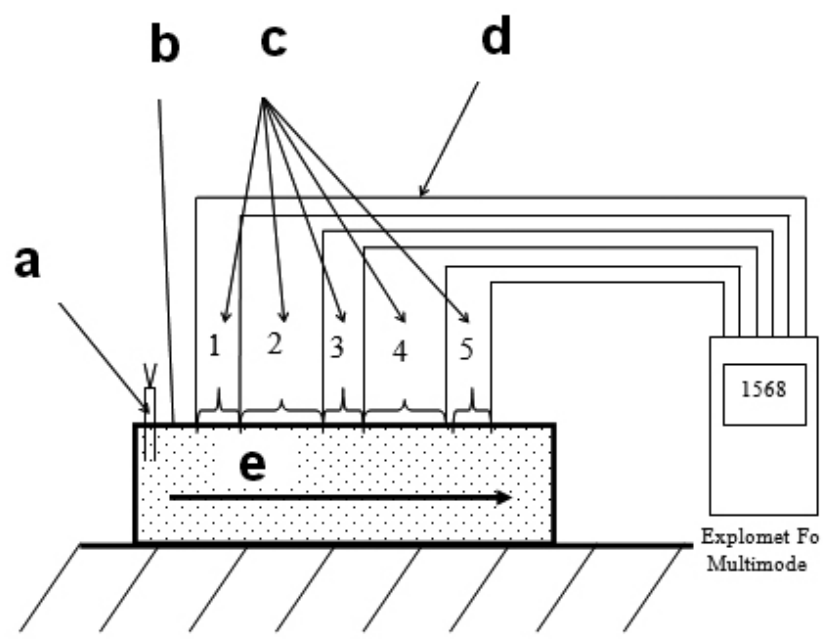

Figure 2. Diagram of the detonation velocity measurement system: a - electric igniter, b - explosive, $\mathrm{c}$ - measurement bases (1-5), $\mathrm{d}$ - probes, $\mathrm{e}$ - direction of detonation

The usable thickness of the charges is 25 to $100 \mathrm{~mm}$ with a recommended detonation velocity of 1800 to $3000 \mathrm{~m} / \mathrm{s}$. Table 2 shows the results of the tests and average detonation velocities for the layer heights.

Table 2. Average detonation velocity $D[\mathrm{~m} / \mathrm{s}]$ measurement results (value $/ \mathrm{x}$ is the number of repeated measurements with accuracy to $10 \mathrm{~m} / \mathrm{s}$ ) for the tested explosive compositions

\begin{tabular}{|c|c|c|c|c|c|c|c|}
\hline \multirow{2}{*}{$\begin{array}{c}\text { ANFO } \\
\text { designation }\end{array}$} & \multicolumn{7}{|c|}{ Charge height $\boldsymbol{H}$ [mm] } \\
\cline { 2 - 8 } & $\mathbf{3 0}$ & $\mathbf{4 0}$ & $\mathbf{5 0}$ & $\mathbf{6 0}$ & $\mathbf{7 0}$ & $\mathbf{8 0}$ & $\mathbf{1 0 0}$ \\
\hline S1 & $2539 / 3$ & - & - & - & - & - & - \\
\hline S2 & $2048 / 3$ & $2126 / 3$ & $2235 / 3$ & - & - & - & $3044 / 3$ \\
\hline S3 & - & $2053 / 3$ & $2172 / 3$ & $2415 / 3$ & - & - & - \\
\hline S4 & - & $2280 / 4$ & - & $2480 / 3$ & - & - & - \\
\hline S5 & $1826 / 4$ & - & $1953 / 3$ & $2206 / 3$ & $2366 / 3$ & $2574 / 3$ & $2716 / 3$ \\
\hline S6 & - & - & $1922 / 3$ & - & - & - & - \\
\hline S7 & $2033 / 3$ & $2339 / 3$ & $2349 / 3$ & - & - & - & - \\
\hline S8 & $1994 / 3$ & - & $2283 / 3$ & - & - & - & - \\
\hline S9 & $1854 / 3$ & $2000 / 4$ & $2052 / 3$ & $2398 / 3$ & - & $2454 / 2$ & - \\
\hline S10 & $1820 / 4$ & - & $1942 / 3$ & - & - & - & - \\
\hline S11 & - & - & - & - & $2140 / 3$ & $2380 / 3$ & $2581 / 3$ \\
\hline
\end{tabular}


The following test plates $300 \times 500 \mathrm{~mm}$ or $500 \times 500 \mathrm{~mm}$ were bonded. For each thickness of the bonded plates, different explosive layer thicknesses were used depending on the weight of the bonding material. All bonding variants were carried out using a single detonation. Metallurgical 1050/AA2519/1050 cladders were used to prepare the multi-layer systems. Figure 3 shows one of the test plate batches.

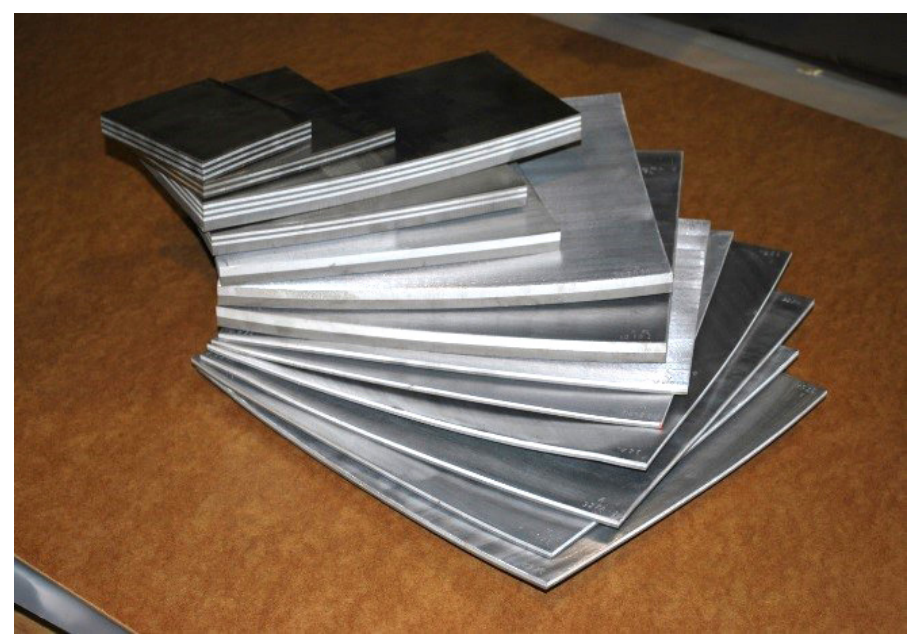

Figure 3. The batch of Ti6A14V/AA2519 test plates

The clad plates (Fig. 4) are subject to detailed evaluation including:

- ultrasonic testing of bond continuity, using straight heads and an Phased Array technique,

- mechanical strength tests; including tensile, bending and peel tests $\left(R_{0}[\mathrm{MPa}]\right)$,

- micro-hardness measurements for different thermal processing conditions,

- evaluation of bond microstructure using electron microscopy to determine the number of intermetallic phases, expressed as the equivalent weld penetration depth factor (RGP).

Table 3 shows the collective data for the selected conditions and the best quality test results for the test plates.

Figure 5 shows an example of the bond area.

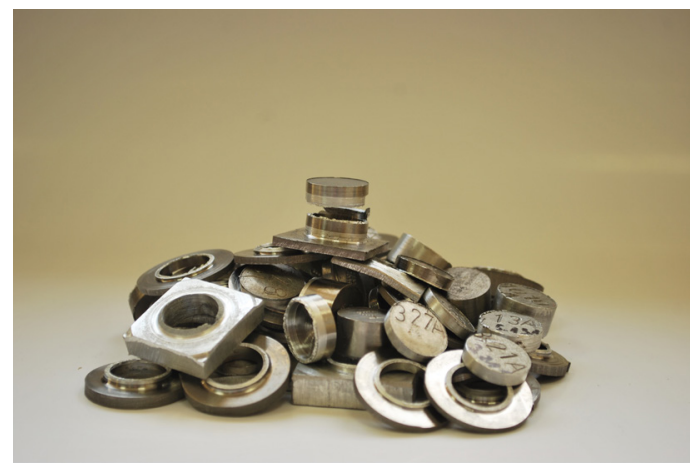

(a)

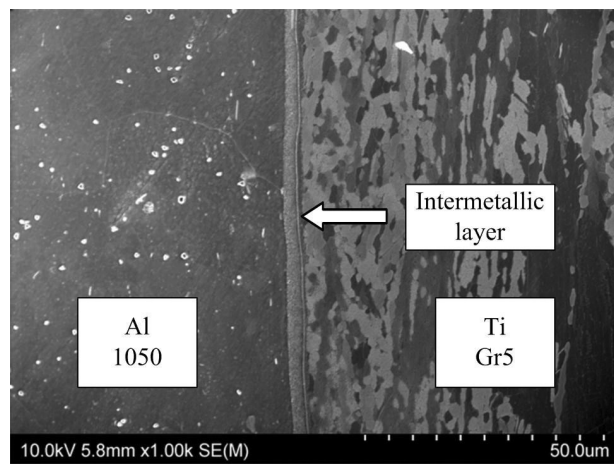

(b)

Figure 4. Tested samples: (a) after peel test; (b) 32A sample SEM projection 
Table 3. Collective data for the conditions and test results for selected test plates

\begin{tabular}{|l|c|c|c|c|c|c|c|c|}
\hline Test no. & AN/FO & $\boldsymbol{H}[\mathbf{m m}]$ & $\boldsymbol{h}_{\mathbf{1}}[\mathbf{m m}]$ & $\boldsymbol{h}_{\mathbf{2}}[\mathbf{m m}]$ & $\boldsymbol{D}[\mathbf{m} / \mathbf{s}]$ & $\boldsymbol{R}_{\mathbf{0}}[\mathbf{M P a}]$ & $\begin{array}{c}\text { Scrap } \\
\text { metal }\end{array}$ & $\begin{array}{c}\text { RGP } \\
{[\mathbf{u m}]}\end{array}$ \\
\hline $3.10 \mathrm{~A}$ & $\mathrm{~S} 2$ & 30 & 2.0 & 10 & 2039 & 156 & $\mathrm{~A} 11050$ & 1.6 \\
\hline $3.17 \mathrm{PL}$ & S9 & 40 & 4.5 & - & 2027 & 155 & $\mathrm{~A} 11050$ & 1.7 \\
\hline 5.5A & S2 & 30 & 1.5 & 15 & 1982 & 185 & $\mathrm{~A} 11050$ & 3.9 \\
\hline 10.6A & S9 & 60 & 1.5 & 25 & 2401 & 171 & $\mathrm{~A} 11050$ & 5.9 \\
\hline 10.9PL & S9 & 50 & 15 & - & 1969 & 214 & $\mathrm{~A} 11050$ & 7.2 \\
\hline M7 & S5 & 100 & \multicolumn{2}{|c|}{$6 \times 3$} & 2730 & 143 & Al1050 & - \\
\hline
\end{tabular}

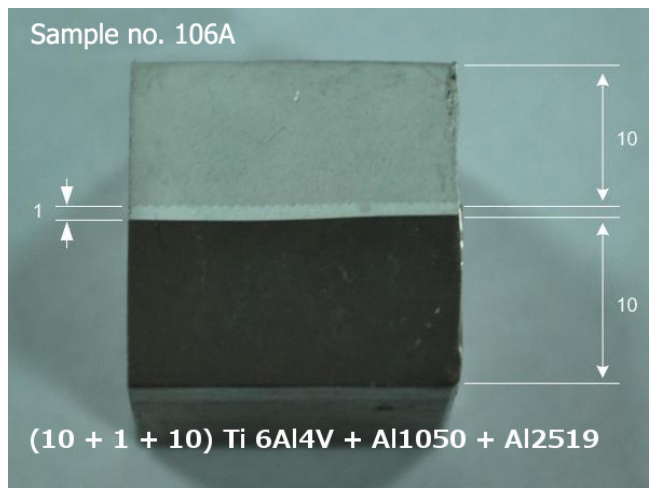

(a)

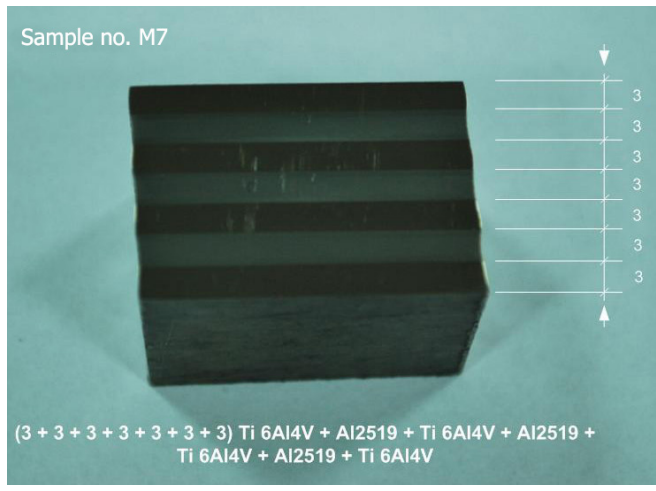

(b)

Figure 5. Macro samples: (a) 106A; (b) M7

\section{Discussion of the results}

The test results validate the process parameters selected for the explosive cladding of AA2519 and Ti6A14V alloys. Among the 80 plates, a permanent bond required to carry out inspection tests was not achieved in 7 cases. Of the variants of direct bonding and bonding with a ductile Al1050 or TiGr interlayer, 2 are feasible. The direct bonds show high mechanical strength, low plasticity in the bonding area and susceptibility to cracking during straightening. The resulting surface area of the bond after straightening can be reduced by $50 \%$ in relation to the initial state. This phenomenum increases with increases in the thickness of the bonded plates. The use of thermal heating in future solutions may not improve plasticity of the bonding area due to possible formation of brittle intermetallic phases between the alloys. The direct bonding variant should be excluded from further research.

A soft metallic Al1050 and TiGr2 interlayer was tested in series ' 3 ' and ' 5 ' plates. In both cases, good quality bonds were achieved, however TiGr2 requires higher accuracy of the geometrical parameters of the explosive system compared to Al1050. Any deviations due to higher plate curvature may result in the loss of bonding and affect larger clad plates. An interesting observation made during the bonding tests was the fact that more impact energy was absorbed by the plates with an aluminium 1050 interlayer than by the plates with an TiGr2 interlayer. The plates made under identical conditions showed a temperature decrease of over $40{ }^{\circ} \mathrm{C}$ when using Al1050, which indicates energy-absorbing structural deformation of the soft interlayer material. The plates may provide better ballistic cover provided that they are not perforated as a result of the puncture test. Price, 10 times lower than that of titanium, is yet another argument for using Al1050. Considering the above, the next stage of research should include the Al1050 interlayer.

An interesting feature of the gradient multi-layered Ti6A14V/AA2519 systems was observed during the tests. The systems show higher resistance to penetration by hollow charges compared to steel plates. This property will be further studied in the next stage of the research project. 


\section{Conclusions}

At the current stage of the project, the results validate the explosive cladding process parameters selected. In further studies, the parameters will be optimized to achieve a high quality bond in larger plates and to evaluate the applicability of bimetals as a new structural material in industrial applications. Special attention should be paid to determining the best heat treatment for the clad plates to remove any stresses in the material structure during cladding and improving the straightening process to achieve maximum strength.

\section{References}

[1] Nowaczewski J., Bozik B., Pluta R., Rudnicki J. Explosive Metal Plate Cladding in Multi-layered Composite Manufacturing. (in Polish) Mater. Wysokoenerg. (High Energy Mater.) 2010, 2: 43-48.

[2] Xia H.-B., Wang S.-G., Ben H.-F. Microstructure and Mechanical Properties of Ti/Al Explosive Cladding. Mater. Des. 2014, 56: 1014-1019.

[3] Mali I.V., Pavliukova V.D., Bataev A.I., Bataev A.A., Smirnov I.A., Yartsev S.P., Bazarkina V.V. Formation of the Intermetallic Layers in Ti-Al Multilayer Composites. Adv. Mater. Res. 2011, 311-313: 236-239.

[4] Zygmunt B. Detonation Parameters of Mixtures Containing Ammonium Nitrate and Aluminium. Cent. Eur. J. Energ. Mater. 2009, 6(1): 57-66.

[5] Shvedor K.K., Dremin A.N. Study of Non-ideal Regimes for the Detonation of Condensed Explosives. (in Russian) Vzryvnoe Delo 1966, 60(17): 33-50.

[6] Maranda A., Nowaczewski J., Włodarczyk E., Zygmunt B. Study on Detonation Properties of Slurry Explosives by Electromagnetic Method. J. Tech. Phys. 1979, 20(1): 19-29.

Polish version:

The study was originally published in Polish, in Materiaty Wysokoenergetyczne (High Energy Materials) journal 2015, 7: 73-79.

English version:

- Revised: November 21, 2020

- Published first time online: December 14, 2020 